\title{
保育室に求められる吸音性能に 関する現場実験
}

\section{A FIELD EXPERIMENT ON PROPER CONDITION OF SOUND ABSORPTION IN KINDERGARTEN CLASSROOM}

野口紗生

上野佳奈子——2

キーワード :

保育施設，音環境，平均吸音率，音響測定，インタビュ一調査，

行動観察

Keywords:

Nursery facility, Sound environment, Average sound absorption coefficient, Acoustic measurement, Interview survey, Behavioral observation

\section{Saki NOGUCHI $* 1$ \\ Kanako UENO $* 2$}

To investigate the sound absorption property necessary to support activities in a nursery classroom, we conducted experiments by installing sound-absorbing materials in the kindergarten classroom. We changed the sound absorption property of classroom in steps, analyzed the change in the sound environment and its influence on activities. As a result, it is suggested that conserving a sound environment supports multifaceted activities in the nursery classroom, and an average sound absorption coefficient of 0.25 or more is necessary to achieve this.

\section{1.はじめに}

心身ともに著しい育ちの時期にある乳幼児たちの過ごす保育施設 では、健やかな生活を送る場、そして豊かな学びの場としての適切 な環境づくりが必要である。中でも音環境は、言語発達や円滑なコ ミュニケーション、情緒の安定にとり重要な役割を担っている。し かしながら現在の日本では保育施設の音環境設計に関する指針は存 在せず、良好な音環境のための配慮の必要性についての認識が低く、 遮音・吸音不足等による残響過多や高い騒音レベルといった課題が 挙げられている。保育者の労働環境との観点からも聴力保護の対象 ともなる点が指摘されており ${ }^{1)} 、$ 保育現場にとって良好な音環境の 保全は極めて重要な課題と指摘できる。

こうした現状の改善に向けて、既往研究では、保育施設での音環 境の実態調查 ${ }^{2)}$ や現場実験 ${ }^{3,4)}$ が行われ、上記課題の解決には保育空 間の吸音性能の向上が有効な手段であることが示されている。これ らの知見を受けて、建築学会が発行する学校施設の音環境保全規 準・設計指針 ${ }^{5)}$ の改定に際しては、保育空間を対象室として加える ベく準備が進められている。しかしながら、具体的な推奨值を定め るための根拠となるデータは少なく、学校の教室の推奨值と同等か、 または言語発達の観点からより優れた性能が必要との指摘 ${ }^{6}$ なども あることからより高い性能が望ましいか、検討が必要である。

以上踏まえ本研究では、保育室に求められる吸音性能を探るため に、保育現場において吸音性能を段階的に変えた条件を設定し、音 環境の変化とそれが保育活動へ及ぼす影響について現場実験をもと に検証した結果を報告する。

\section{表 1 対象室の諸元}

\begin{tabular}{ll}
\hline 床面積/表面積 $\left[\mathrm{m}^{2}\right]$ & $51.6 / 181.4$ \\
\hline 室容積 $\left[\mathrm{m}^{3}\right]$ & 122.2 \\
\hline 園児数 $[$ 人 $]$ & 29 \\
\hline \multirow{3}{*}{ 仕上げ材 } & 床: フローリング \\
& $\begin{array}{l}\text { 壁 : 石膏ボード } \\
\text { 天井 : 化粧石膏ボード }\end{array}$ \\
\hline
\end{tabular}

\section{2. 方法}

\section{1 対象}

音環境の重要性についての理解が得られた協力園において、仕上 げに吸音材の使われていない室を対象とした。対象室の概要を図 1 、 諸元（ロッカー室部分除く）を表 1 に示す。当該園は神奈川県横浜 市に 1956 年に設立された幼稚園で、現在は 3〜 5 歳児の年齢別保育 が行われている。各保育室の天井には仕上げ材として岩綿吸音板が 使用されているが、 4 歳児室のうち 1 室は、倉庫として利用されて いた部屋を保育室として転用しており、吸音効果のある材料は使用 されていない。このクラスを担当する保育者も室内の響きを気にし ていたことから、この保育室を対象として音環境改善に向けた吸音 材の設置実験を実施した。

\section{2 実験概要}

実験スケジュールを表 2 に示す。本実験では、保育室に適切な吸 音の程度を探るために、吸音材未設置条件 (A: 平均吸音率 $\bar{\alpha}=0.14$ )、 できる限り多く吸音材を設置した条件 (B: $\bar{\alpha}=0.3$ )、学校教室の推 奨值と同等の条件 (C: $\bar{\alpha}=0.2)$ 、及び実験の経過を踏まえ設定した 条件 B と条件 C の中間の条件 (D: $\bar{\alpha}=0.25) の 4$ 条件での比較を行 った。また、保育活動への適性について保育者の評価を手掛かりと するために、はじめに変化を捉えやすい条件を提示し、その後学校 教室の推奨值へと変更した際に活動に支障がないのかを検証してい くプロセスを採った。

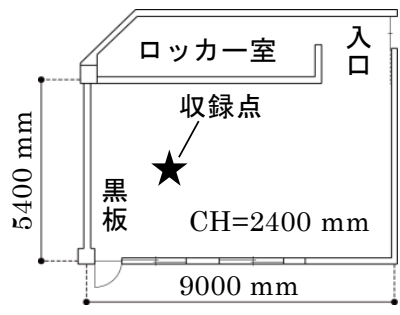

(a) 平面図

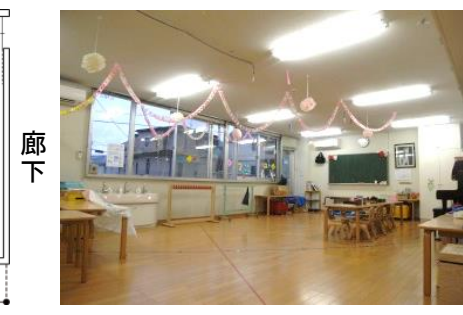

(b) 内観
図 1 対象室概要

本稿は日本音響学会春季研究発表会 (埼玉，2017 年 9 月）での発表内容にデー夕を追加し、加筆・修正を加えたものである。

明治大学研究・知財戦略機構 研究推進員・博士 (国際情報通信学) ( 和 214-8571 川崎市多摩区東三田 1-1-1)

2 明治大学理工学部建築学科 教授・博士 (工学)

Post-doctoral Research Fellow, OSRI, Meiji Univ., Dr. GITS

2 Prof., School of Science and Technology, Meiji Univ., Dr. Eng. 
条件毎に音環境の変化と保育活動への影響を捉えるために、発生 音の収録、活動の観察、及び担任保育者への意識調查 (アンケート・ インタビュー) を行い、吸音性能との対応を検証した。

\section{3 実験条件}

対象室内の天井に、多孔質吸音材を取り付けた。吸音材の設置状 況を図 2 に示す。吸音材には磁石を取り付けたポリウール片（170 $\times 400 \times 50 \mathrm{~mm}$ ，ポリエステル製多孔質吸音材，フコク社製）を用い、 天井の仕上げ材を固定している鉄製ネジに磁力で接着する方法 ${ }^{3)}$ 設置した。実験で設定した吸音条件を表 3 に、折り紙インパルス音 源 ${ }^{7)}$ を用いて測定した各条件での残響時間の測定結果を図 3 に示す。 表 3 内の平均吸音率は、文献 5) に従い、残響時間実測值より Sabine の式を用いて算出したものである。ポリウール片の設置個数は、条 件 B では空調・照明設備等を避け可能な限り多く設置した個数であ り、条件 C, D では $1 \mathrm{kHz}$ 帯域での平均吸音率の目標值を達成するよう 残響時間を測定しながら調整した個数である。なお、条件 C, D では 条件 B と比べてポリウール片 1 片あたりの吸音効果が大きく、これ はポリウール片側面の吸音効果によるものと考えられる。

\section{4 調査方法}

音環境の変化が保育活動へ及ぼす影響を捉えるために、音環境調 查、保育者への意識調查、観察調査を行った。

音環境調査では、騒音計マイクロフォン（RION NL-42）及びレコ ーダー（OLYMPUS DS-901）を用いて発生音の収録を行った。収録時 間は子どもたちが登園し終えて朝の集いが始まる直前の 10:00 から 帰りの集いが終了寸る 14:00 とし、レコーダーのタイマー録音機能 を用いて連日同時間の収録を行った。収録データから、調查(1)〜 (6) (表 2)：条件 A（設置前 1,2 - 取外し後）、B、C、D 期間より通常保 育であった各 4 日（4)のみ 3 日）、計 23 日分のデータを抽出し、 1 分間毎に等価騒音レベル $L_{\mathrm{Aeq}, 1 \mathrm{~min}}$ を算出した。なお分析対象となる室 内で活動している時間帯は全体の $86 \%$ であった。

保育者への意識調查では、対象室の担任 1 名を対象とし、はじめ に音環境、子どもの様子、保育者自身への影響についての項目に 5 段階で評価するアンケート（保育者評価シート）を記入してもらっ た後、記入内容をもとにインタビューを行う形で実施した。初回は 現状についての考えを、2 回目以降は前回までと比較しながら回答 してもらった。

観察調查では、筆者らの他に保育学の研究者 2 名、計観察者 4 名 が各期間に 1,2 日クラスを訪問し、ビデオデータの取得とノート の記録を行った。保育、音環境の観点から記録をとることを中心に、 音環境、子どもの様子についての評価シート（観察者評価シート） への記入を行い、日による変化や印象について情報共有を行いなが ら効果を検証した。

\section{3. 結果と考察}

\section{1 音環境の変化}

実験前の通常保育日の典型的な 1 日の $L_{\text {Aeq, } 1 \text { min }}$ の推移と活動内容を 図 4、活動の様子を図 5 に示す。遊び (10:00-10:20, 12:00-12:50) や昼食（11:30-12:00）等の自由な活動時は 80-85 dB 程度の時間帯 が多く、高い值で推移している。集い等の集団での活動時 (10:30-11:30，13:30-14:00）は、全員で歌う時には 85dB 以上、そ の他発声を伴う時には $80 \mathrm{~dB}$ 程度とレベルが高くなっている一方で、
表 2 実験スケジュール

\begin{tabular}{|c|c|c|}
\hline \multirow[t]{2}{*}{$\begin{array}{c}2017.10 .17 \sim \\
10.31 \\
\end{array}$} & $\begin{array}{l}\text { 調査(1)：条件 A(設置前 1) } \\
\text { 意識調査 }\end{array}$ & 条件A \\
\hline & \multicolumn{2}{|l|}{ 吸音材の設置＜条件 $\mathrm{A} \rightarrow$ 条件 $\mathrm{B}>$} \\
\hline $11.06 \sim$ & 調査(2)：条件 $\mathrm{B}(\bar{\alpha}=0.3)$ & $\frac{1}{\text { 圣件 } \mathrm{B}}$ \\
\hline \multirow{2}{*}{11.17} & 意識調査 & 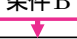 \\
\hline & \multicolumn{2}{|l|}{ 吸音材一部取外し<条件 B $\rightarrow$ 条件 $C>$} \\
\hline \multirow{3}{*}{$\begin{array}{l}11.20 \sim \\
12.01\end{array}$} & 調査（3：条件 $\mathrm{C}(\bar{\alpha}=0.2)$ & $\frac{1}{2}$ \\
\hline & 意識調査 & 策件し \\
\hline & \multicolumn{2}{|l|}{ 吸音材取外 し<条件 $\mathrm{C} \rightarrow$ 条件 $\mathrm{A}>$} \\
\hline $12.04 \sim$ & \multirow{2}{*}{$\begin{array}{l}\text { 調査(4)：条件 A(取外し後) } \\
\text { 意識調査 }\end{array}$} & 1 \\
\hline 12.14 & & 条件A \\
\hline \multirow[t]{2}{*}{$2018.01 .15 \sim$} & \multicolumn{2}{|l|}{ 調査(5)：条件 $\mathrm{A}($ 設置前 2) } \\
\hline & \multicolumn{2}{|l|}{ 吸音材の設置く条件 $\mathrm{A} \rightarrow$ 条件 $\mathrm{D}>$} \\
\hline $01.22 \sim$ & 調査 6 ：条件 $\mathrm{D}(\bar{\alpha}=0.25)$ & 冬件D \\
\hline 02.02 & 意識調査 & 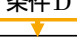 \\
\hline
\end{tabular}

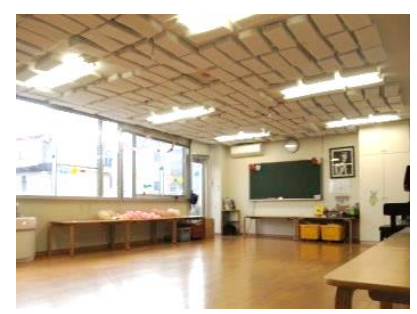

(a) 条件 B

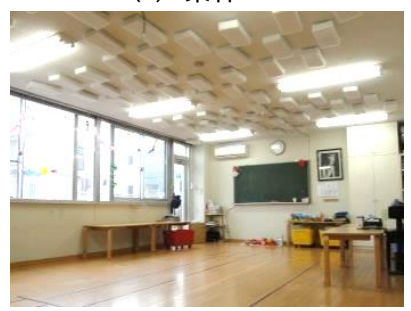

(c) 条件 D

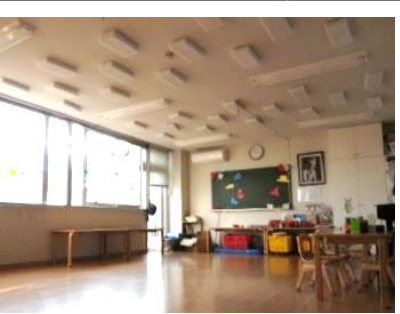

(b) 条件 C

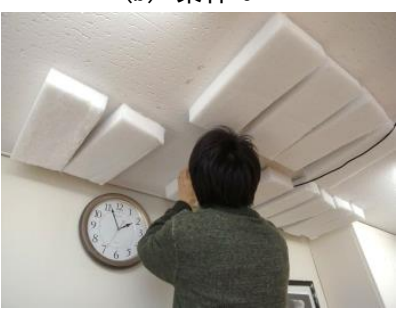

(d) 設置の様子
図 2 吸音材設置状況

表 3 実験で設定した吸音条件

\begin{tabular}{|l|c|c|c|c|}
\hline 条件 & 条件 $\mathrm{A}$ & 条件 $\mathrm{B}$ & 条件 C & 条件 $\mathrm{D}$ \\
\hline 設置面積(天井面) $\left[\mathrm{m}^{2}\right]$ & & 22.8 & 3.1 & 7.5 \\
設置面積割合 & & $44.3 \%$ & $5.9 \%$ & $14.5 \%$ \\
ポリウール片·設置個数 & & 336 個 & 45 個 & 110 個 \\
\hline 残響時間 $(1 \mathrm{kHz})[\mathrm{s}]$ & 0.77 & 0.36 & 0.54 & 0.44 \\
\hline 平均吸音率 $(1 \mathrm{kHz})$ & 0.14 & 0.30 & 0.20 & 0.25 \\
\hline
\end{tabular}

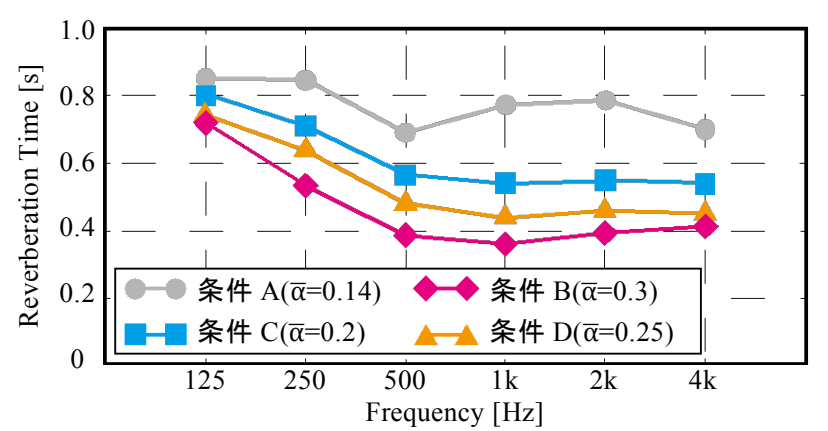

図 3 各条件での残響時間

読み聞かせや話を聞く場面では $70 \mathrm{~dB}$ を下回っており比較的静かな 環境が形成されていた。活動の流れは日ごとに異なるが、登園時と 降園時の遊び、昼食は共通であった。昼食は 11:20～12:20の間に開 始された。弁当であることから準備時間は短く、準備が整うと全員 での「いただきます」の歌、挨拶の後に食べ始めた。開始直後は会 話を楽しみながら食事をしており比較的静かであったが、その後発 
声が増えたり食べ終えた子どもから順に室内で遊び始めると 80-85dB 程度へと徐々に高いレベルに推移していた。遊び時は、子 ども自身が机や椅子、マットなどを配して好きな場所を設定し、ブ ロックやカプラなどの構成遊び、鍋等を使用したごっこ遊び、制作 遊びなどを行っていた。85dB 程度の高いレベル時の発生音は、子ど もの大きな声や、ブロックやカプラが床に落ちる音、鍋を吒いたり する音であった。

上記特徵を踏まえ、音環境の変化を捉えるために、毎日実施され る昼食時 (「いただきます」から 10 分間)、自由遊び時（「いただき ます」の 30 分後から 30 分間）を分析対象とした。昼食時、遊び時 についての各日の $L_{\mathrm{Aeq}, 1 \mathrm{~min}}$ の算術平均值及び各条件 4 日間 (3)の遊び 時及び(4)のみ 3 日間) の平均值を図 6 に、各条件 (条件 A は(1)のみ) の $L_{\text {Aeq, Imin }}$ の頻度分布を図 7 に示す。

図 6 に着目寸ると、日による変化も見受けられるものの、平均值 は昼食時、遊び時ともに条件 B, D で低減している傾向が捉えられた。 (1) 条件 A（設置前 1) より (2)条件 B では各活動とも約 $3 \mathrm{~dB}$ の低減が確 認され、その後(3)条件 C、(4)条件 A（取外し後）は(1)条件 A（設置前 1）と近いレベルに戻った。(5)条件 A（設置前 2) では冬休み明けで 落ち着いた䨌囲気であったことも影響し、特に昼食時はレベルの低 減傾向がみられたが、(6)条件 D ではさらに遊び時のレベルも(2)条件 B と同等のレベルに下がった。図 7 頻度分布では、各活動とも(2)条 件 B、(6)条件 D では吸音性能が高くなるにつれて低いレベルの分布 割合が多く、(1)条件 A（設置前 1)，(3)条件 C では高いレベルへの分 布割合が多いことが確認できる。

以上より、昼食時、遊び時といった同時多発的に音が発せられる 場面では、平均吸音率 $0.25,0.3$ の 2 条件で、吸音性能が騒音レ心゙ ルの低減に有効であったことが示唆された。

\section{2 保育活動への影響}

担任保育者 1 名への意識調查及び保育活動の観察調查の結果と 3.1 の結果を踏まえ、音環境の変化が保育活動へ及ぼす影響につい て考察する。当該保育者は経験年数 5 年以内で、どの場面でも穏や かに、落ち着いた態度で子どもに接しており、声も抑えめである。 インタビュー時には自身の保育行為の根拠を丁寧に話すなど、非常 に自覚的に保育を行っていることが捉えられた。

保育者へのアンケート結果を図 8 に、インタビュー結果を表 4 に 示す。図 8 より、条件間を比較すると、全体的に条件 A, C はネガテ イヴな評価、条件 B，Dではポジティヴな評価の傾向にあることがわ かる。これはインタビュー時の回答からもうかがえ、条件 B, D では 音の聞こえ方、子どもの落ち着き、保育のしやすさともに向上した ことが、条件 C では条件 A との違いは大きく感じられたものの音環 境への不快感や音の聞きとりにくさがあることが、語られた。

音の聞こえ方の面では、条件 A では「耳が痛い」「うるさい」「不 快感を感じる」という回答が多く、条件 C でも同様の傾向で受け取 られていた。観察者も同様で、条件 A では特に一つ一つの音が増幅 され、甲高く耳をつくような印象を受けた。条件 B, D では不快な印 象がなくなり活動の際に生じる音を「その（人の、物の）音」とし て聞けるようになり耳の痛みを感じなくなったようであった。

子どもの様子への影響では、条件 A, C では声が大きくなった様子 が保育者及び観察から捉えられ、子どもも「うるさい」「耳が痛い」 と感じているようであった。条件 B, D ではコソコソ話や会話を楽し

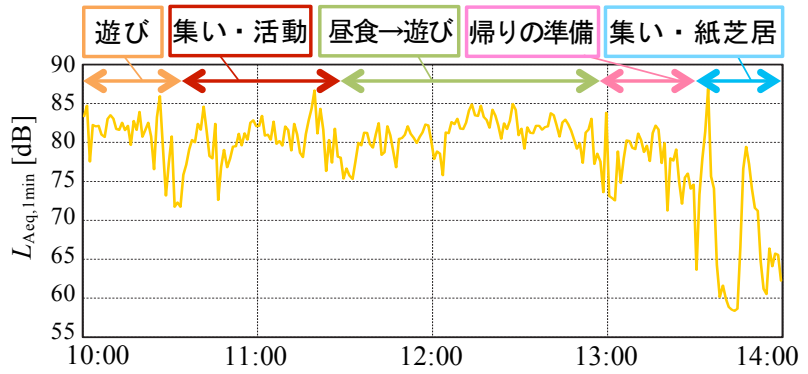

図 4 1 日の等価騒音レベル $\left(L_{\mathrm{Aeq}, 1 \mathrm{~min}}\right)$ の推移と活動内容

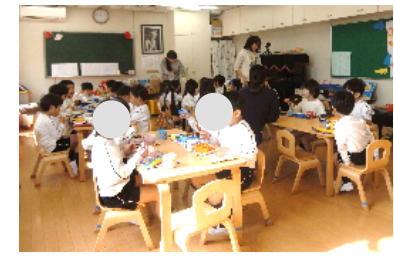

（a）昼食時

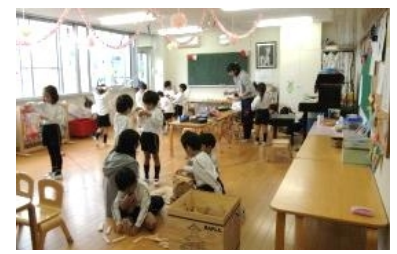

(b) 遊び時
図 5 活動風景

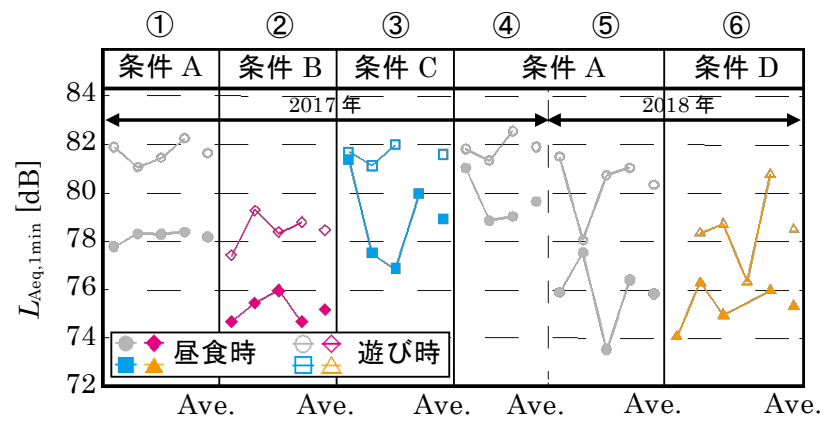

図 6 等価騒音レベル $\left(L_{\mathrm{Aeq}, 1 \mathrm{~min}}\right)$ 平均值の日毎・条件ごとの推移

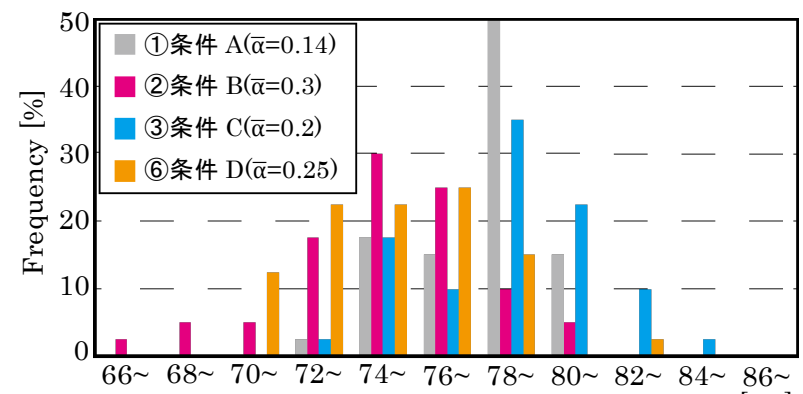

(a) 昼食時

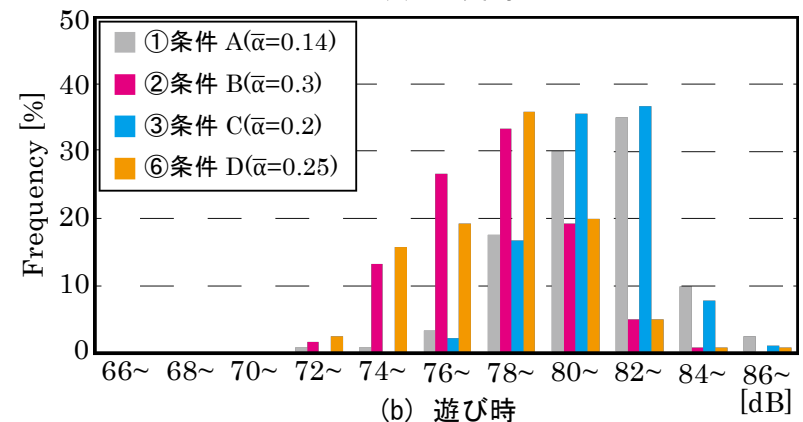

図 7 等価騷音レベル $\left(L_{\mathrm{Aeq}, 1 \mathrm{~min}}\right)$ の頻度分布

む姿がみられ、落ち着きが捉えられたとともに、保育者の呟きを聞 くようになり、保育者が全体の注意を集めずとも（片付ける、集ま るなどの）意図を共有できるようになったようであった。

保育への影響としては、条件 A, Cでは音環境が不快にならないよ うに「子どもに声の大きさについて伝える」「音遊びをしている子ど 
もを他の遊びに誘う」「(保育者の) 発する音を抑制する」ことに意 識が向けられていた。条件 B, D ではそのような抑制の必要がなくな ったことに加えて、「子どもの呟きを聞けるようになった」「歌いや すい、言葉を大切にできそう」などの変化が捉えられた。これらの 影響は、(1)条件 A（設置前 1）には「音のみの問題であり保育への影 響はない」と考えられていたが、(2)条件 B 時に保育自体や子どもへ の影響もある重要な問題であるとの認識へと変わったようであった。 保育行為としても、(2)条件 B 時の体験後、(3)条件 C, (4)条件 A（取外 し後）時に、意識的に小さな音で伴奏している、控えめな声で読み 聞かせをしている、合図にピアノ音を用いるなど、顕著な行動変化 が確認された。(2)条件 B 時の良好な音環境の体験が音の面での保育 意識の向上へとつながったといえる。また、「子どもの呟きを聞ける」 といった聞く面への影響も大きな変化と捉えられていた。クラス全

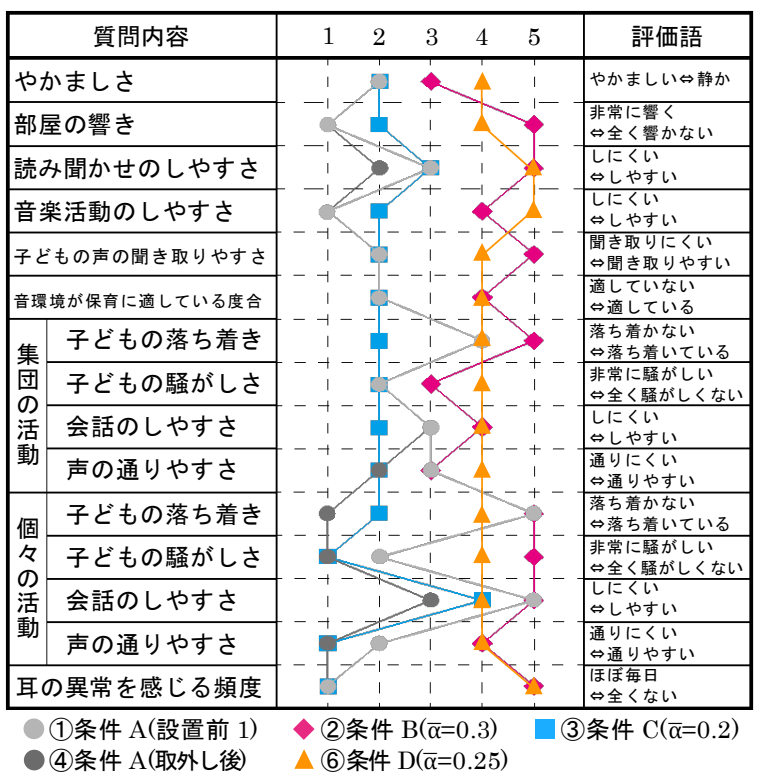

図 8 保育者へのアンケート結果
体を見渡しながら保育を行う必要のある保育者にとり、子どもの呟 きを聞き取れるということは、子どもの様子を把握しやすくするこ とを支えると推察できる。観察時には、遊びの場面において、子ど もの元へ行く・または様子を見る、興味を持っていそうな環境を提 案する、など具体的な援助の判断に影響を及ぼしていることがうか がわれた。さらに、聞き取りやすさの向上は「言葉を大事にするこ とへとつながる」との指摘もあり、例えば歌詞の意味を考えて歌つ たり、お互いの思いを感じながら会話をするなど、活動の質への影 響も重要とみられた。これら (2)条件 B 時に向上したと評価された保 育行為への影響については、(6)条件 D 時も同等と受け取られていた。 観察時も、(2)条件 B, (6)条件 D ではピアノ合図音などの使用はみら れず、また音遊びや音の抑揚をつけて盛り上がることを楽しむ姿が みられた。

実験全体を振り返って保育者に各条件を比較してもらったところ、 条件 D（ $(\bar{\alpha}=0.25 ）$ 以上の性能が必要であり、条件 C $(\bar{\alpha}=0.2)$ では不 足を感じたとの回答が得られた。条件間の変化としては、条件 $\mathrm{C}$ $(\bar{\alpha}=0.2)$ から条件 A（ $\bar{\alpha}=0.14 ）$ 一の変化が最も大きく感じられてお り、吸音材を使用していない室の使い難さがうかがわれた。

以上より、平均吸音率 $0.25,0.3$ 条件で保育者から良好な評価が 得られ、音環境の改善は音の聞こえ方とそれによる居心地や、子ど もの行動、そして保育行為へと影響することが捉えられた。本事例 では保育者の意識的かつ丁寧な保育により、音環境に恵まれていな い状況でも遊びや子ども同士、保育者との関係は良好である様子が みられたものの、音環境改善がより良い保育実践の一助となる可能 性が示された。

\section{4. 総合考察}

保育室に求められる吸音性能の検証を目的として現場実験を実施 した結果を以下にまとめる。

• 平均吸音率 0.2 以下の条件では、自然発生的な音が増大しにぎや

表 4 保育者へのインタビュ一結果

\begin{tabular}{|c|c|c|c|c|}
\hline & 条件 $\mathrm{A}[\mathrm{O}$ :(1)設置前 1,@：(4)取外し後] & (2)条件 $\mathrm{B}(\bar{\alpha}=0.3)$ & (3)条件 $\mathrm{C}(\bar{\alpha}=0.2)$ & (6)条件 $\mathrm{D}(\bar{\alpha}=0.25)$ \\
\hline & $\begin{array}{l}\text { O物の音 (カプラや金属)、一斉になる } \\
\text { 音(歌声・楽器) は聑が痛い } \\
\text { O遊び時、近く声も聞きりにくく } \\
\text { 全ての音が広がるように感じる } \\
\text { 条件 Cよりも音が室全体に広がるよ } \\
\text { うに感じ、どこで何の遊びが起きてい } \\
\text { るか分からない } \\
\text { 聂が痛むこともささらに増えた }\end{array}$ & $\begin{array}{l}\cdot \text { ·物の音を(嫌な音ではなく) その物の音と } \\
\text { して聞けるようり、耳の痛みがない } \\
\cdot \text { ·遊び時に音が押し寄せる感じはなくなり、 } \\
\text { 音や言葉の一音一音が聞き取りやすい } \\
\cdot \text { 子どもが大きな声で歌っても、単に大きな } \\
\text { 音として聞ける }\end{array}$ & 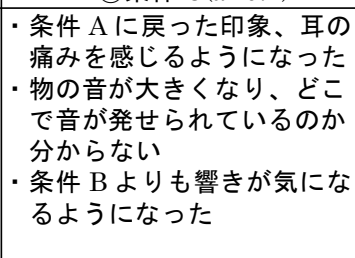 & $\begin{array}{l}\cdot \text { 耳の痛みはない } \\
\cdot \text { 条件 B との違い（多少音が } \\
\text { 大きくなった）は若干感じ } \\
\text { るものの、ほぼ同様の印象 }\end{array}$ \\
\hline & $\begin{array}{l}\text { O「なんでこのクラスってうるさいんだ } \\
\text { ろうね」と言う子どもがいた } \\
\text { 周りの音に負けないように、子どもの } \\
\text { 声が明らかに大きくなった } \\
\text { 特定の子どもが耳を抑えることが多 } \\
\text { くなった }\end{array}$ & $\begin{array}{l}\text { ·遊び時、子ども同士でコソコソ話したり遠 } \\
\text { くの人に声を届けるなど、会話を楽しむ場 } \\
\text { 面が見られたた } \\
\text { 子息もが担任の呟きをすごく聞いていた } \\
\text { 印象だった } \\
\text { ·部屋が広くなった?」と言う子どもがいた }\end{array}$ & $\begin{array}{l}\text { ·子どもの声が大きくなった } \\
\text { ·遊び時、「また耳が痛くなっ } \\
\text { たね」と言う子どもがいた }\end{array}$ & $\begin{array}{l}\text { ·遊び時、子どもが別の場所 } \\
\text { の遊びにも気づけるように } \\
\text { なったと感じる } \\
\text { ·聴覚過敏の子どもが、缶を } \\
\text { 使った楽器遊びをするよう } \\
\text { になった }\end{array}$ \\
\hline & 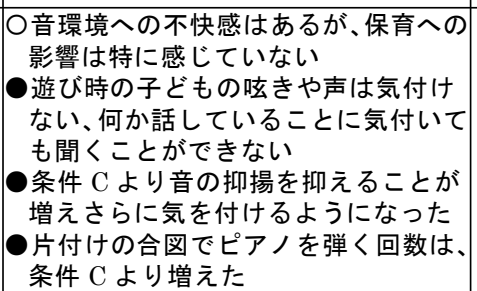 & 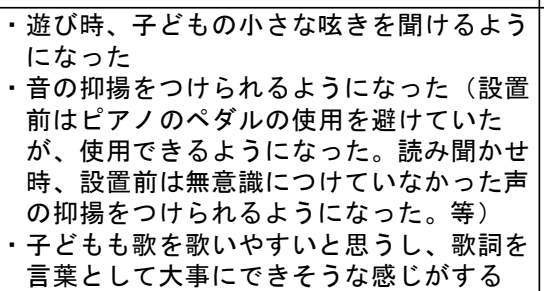 & 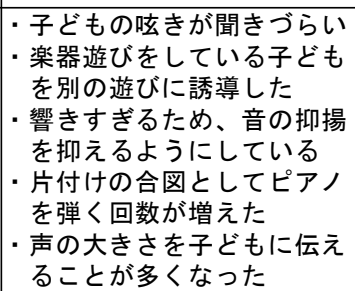 & $\begin{array}{l}\text { ·遊び時、別の場所の遊びに } \\
\text { 気を配り、反応できる } \\
\text { ·読み聞かせや音楽活動のし } \\
\text { やすさは条件 B と同様 } \\
\text { •物をたたく楽器遊びなど音 } \\
\text { を楽しむ遊びができるよう } \\
\text { になった }\end{array}$ \\
\hline & & & & \\
\hline
\end{tabular}


かになりやすく、耳の痛み、音の聞きとりにくさ等の問題が生じ、 保育のし難さ、活動の抑制へと影響寸る

・平均吸音率 0.25 以上の条件では、耳の痛みはなく、音が聞き取り やすくかつ発生音の抑制の必要がなくなり、子ども・保育者が瓦 いに聞くことや音・声を活用し楽しむこと等、より良い保育実践 へとつながる

・平均吸音率 0.25 条件は 0.3 条件より若干音が大きい印象が持たれ るものの、保育活動へ及ぼす影響は同等に良好である

以上より、保育室には平均吸音率 0.25 以上の吸音性能が求められ ることが示唆された。なおこの值は、言語発達の観点から低年齢の 子どもにとり学校教室よりもすぐれた吸音性能が必要との指摘 ${ }^{6)}$ 、 及び筆者らがこれまで実施した吸音材設置実験において、自由な活 動場面では平均吸音率 0.2 よりも 0.3 の方が好ましいとの見解 ${ }^{8,9}$ と矛盾しない值である。

本研究を通して、保育の場では、自由遊びなど同時多発的に音が 発せられる場面でもにぎやかになりすぎず、子ども・保育者が互い を聞くことや音の抑揚を楽しむことを支えるための音環境が必要で あり、そのためには学校教室での推奨值よりも高い性能が求められ ることが示された。学校施設の音環境保全規準・設計指針において は、天井面の吸音によって平均吸音率 0.2 程度が確保できる ${ }^{5)}$ とさ れているが、保育空間ではより高い吸音性能が必要とされることか ら、壁面や家具などへの吸音の付加 ${ }^{10)}$ を含めて、吸音性能の向上方 法を検討し、普及を図る必要がある。

\section{謝辞}

音環境への問題意識を持ち、本研究実施に快くご協力くださった 鶴見大学短期大学部附属三松幼稚園の先生方、保育の観点からご助 力賜りました千葉明徳短期大学由田新先生、鶴見大学短期大学部片 川智子先生に心より謝意を表します。また本研究は JSPS 科研費 16H03274 の助成を受けた。

なお本実験は明治大学大学院(当時)富永玩磨氏の修士論文の一部 としてまとめられたものである。同氏の本研究遂行への貢献及び明 治大学（当時）芦刈勇磨氏の実施協力に謝意を表する。

\section{参考文献}

1)川井:保育所等における音の問題, 騒音制御, Vol.39, No.3, pp.58-62, 2015.6 2)上野, 宮塚, 野口, 船場, 倉斗 : 音環境に着目した保育施設の実態調査, 日本建築学会環境系論文集, Vol. 82, No.732, pp.87-95, 2017.2.

3)川井，丸山：保育室の吸音による音環境の向上:容易に着脱可能な仮設吸音 体を用いた現場参加型実験, 日本騒音制御工学会秋季研究発表会講演論文 集, pp.193-196, 2016.11.

4)宮塚，武岡，上野：保育空間に適した吸音材設置手法の検討，日本音響学 会騒音振動研究会資料，N2015-44，2015.08.

5) 日本建築学会 : 学校施設の音環境保全規準・設計指針, 2008 .

6)川井：保育施設の音環境保全に向けて 一海外規準と我が国における取り組 み-, 日本音響学会誌, Vol.72, No.3, pp.160-165, 2016.3.

7)豊田，杉江，吉村：折り紙インパルス音源の音響特性 一残響時間測定への 適用一, 日本音響学会建築音響研究会資料, AA2008-68, 2008.12.

8) 富永, 野口, 宮塚, 渡邊, 上野: 保育環境への吸音材導入に向けた取組み 認定こども園こどもむらでの実践：その 1-, 日本音響学会 2017 年春季研 究発表会講演論文集, pp.917-920,2017.3.

9)富永, 野口, 上野, 川井, 由田, 片川: 保育室への吸音材設置による効果
の検証 一千葉明徳短期大学附属幼稚園におけるケーススタディー, 日本音響 学会 2017 年秋季研究発表会講演論文集, pp. 1097-1100, 2017.9

10)川井, 佐藤, 野口, 船場：ドイツ・ミュンヘン市域における保育施設の音 環境設計に関する視察調査, 日本建築学会技術報告集, Vol.24, No. 58, pp. 1083-1086, 2018. 10.

[2018 年 10 月 3 日原稿受理 2018 年 11 月 30 日採用決定］ 